\title{
SANTOS REYES. VIRTUOSOS INCAS. ANTIGUOS TIRANOS: IMAGEN DE LA MONARQUÍA EN LA HOMILÉTICA SAGRADA RIOPLATENSE (SS. XVIII-XIX)
}

\author{
Santos reyes. Virtuosos Incas. Antiguos tiranos: the image of the monarchy \\ in the sacred river plate homiletics (SS. XVIII-XIX)
}

Javier A. Berdini*

\begin{abstract}
Resumen
La homilética fue un instrumento de defensa del orden político establecido o de crítica al régimen en decadencia que puede caracterizarse como un discurso religioso con fuerte contenido doctrinal e ideológico que alcanzaba a un amplio auditorio. Se pronunciaba en fiestas marianas, exequias del monarca o celebraciones cívico-religiosas. Buscaba construir modelos ideales de comportamiento transmitiendo valores y representaciones desde la cosmovisión católica; pero también fueron creadores y difusores de opinión, como piezas de teología política en las que se buscaba legitimar a la Corona o al gobierno revolucionario. Se tomaban así como figuras ideales a los santos, la Virgen o a los reyes canonizados. Se analiza aquí qué imagen de la monarquía se predicaba en general y el conjunto de ideas y creencias que sobre la figura de los monarcas españoles en particular se construyeron durante los períodos tardo-virreinal y revolucionario, en los que no dejaban de incidir los avatares político-revolucionarios y los proyectos de organización institucional.
\end{abstract}

$$
<\text { Homilética }><\text { Monarquía }><\text { Representación }><\text { Imaginario }>
$$

\begin{abstract}
Homiletics were an instrument of defense of the established political order, as well as an instrument of criticism of the regime in decline. They can be characterized as a religious speech with a strong doctrinal and ideological content that reached a wide audience. The homiletics were delivered in Marian feasts, in funerals of the Monarchy or at civil-religious celebrations; they intended to build ideal models of behavior and to transmit values and representations from the Catholic world view. Moreover, they were opinion creators and opinion diffusers as pieces of political theology in which they wanted to legitimize the Crown or the revolutionary government. The saints, the Virgin and the canonized kings were taken as ideal figures. In this article, I analyze what was the image of the monarchy preached in general, and the set of ideas and beliefs shaped on the figure of the Spanish monarchs in particular, during the late-colonial and revolutionary periods, a moment where the political and revolutionary changes, and the projects of institutional organization continued to exert influence.
\end{abstract}

$<$ Homiletics $><$ Monarchy $><$ Representation $><$ Imaginary $>$

Recibido: 10/05/2016 // Aceptado: 16/09/2016

* Profesor en Historia. USal. jberdini@gmail.com 


\section{DOSSIER}

Berdini. Santos reyes. Virtuosos incas. Antiguos tiranos: imagen de la monarquía en la homilética sagrada rioplatense...

\section{Introducción}

La homilética sagrada fue un instrumento de defensa del orden político establecido o de crítica al régimen en decadencia transmitiendo valores, ideas y representaciones que puede caracterizarse como un discurso religioso con fuerte contenido doctrinal e ideológico que alcanzaba a un amplio auditorio. ${ }^{1}$ En palabras de Valentina Ayrolo, fueron un canal informativo que "vehiculizó explicaciones acerca del mundo social, político y "celeste", siendo además, una herramienta tanto eclesiástica como política (Ayrolo, 2009). Buscaba construir modelos ideales de comportamiento transmitiendo valores y representaciones desde la cosmovisión católica; pero también fueron creadores y difusores de opinión, como piezas de teología política en las que se buscaba legitimar a la Corona o al gobierno revolucionario (Martínez de Sánchez, 2008, 2010, 2013, 2014; Fenoglio, 2010).Por lo tanto, los sermones colaboraron para que se operara un proceso de construcción de arquetipos o modelos, en ocasión de distintos acontecimientos y celebraciones religiosas o cívicas. Los predicadores buscaban así instalar en la sociedad de su tiempo modos de pensar y actuar relacionados con la doctrina y moral católica. Esa homilética será abordada para analizar qué imagen de la monarquía se predicaba en general y el conjunto de ideas y creencias que sobre la figura de los monarcas españoles en particular se construyeron durante los períodos tardo-virreinal y revolucionario. La imagen de la monarquía que se trasladó a los súbditos del rey (y luego habitantes de las Provincias Unidas) en esos dos momentos (tardocolonial, fines del siglo XVIII y la primera década revolucionaria) estuvo inserta en los avatares políticos y los proyectos de organización institucional desde sus inicios con la Revolución de Mayo (1810) pasando por la Declaración de la Independencia (1816) hasta el final del Directorio. Entendidos así los sermones como piezas de teología política, será posible comprenderlos como transmisores de un conjunto de ideas, nociones, creencias y valores sobre la figura del monarca, tanto español como aborigen en esos dos períodos históricos ya nombrados.

\section{Fuentes documentales}

Las fuentes o sermones a analizar fueron en su momento oralizados, discursos religiosos pronunciados por alguna celebración litúrgica (fiestas marianas), honras fúnebres (en las exequias del monarca ${ }^{2}$ y de soldados caídos en batalla) o cívicas

\footnotetext{
1 Este artículo es un avance de investigación en el proyecto "El 'deber ser' en la oratoria sagrada rioplatense (Siglos XVIII y XIX)” dirigido por el Dr. Silvano Benito Moya. El proyecto se propone estudiar cómo la oratoria sagrada ayudó a construir arquetipos paradigmáticos en la sociedad colonial y postcolonial, durante los siglos XVIII y XIX. El mencionado proyecto es la continuidad de los trabajos de investigación del Programa de Estudios Indianos (Centro de Estudios Avanzados, Universidad Nacional de Córdoba) que ha investigado sobre sermones coloniales y poscoloniales del actual territorio de Argentina.

2 Un autor francés explicará la importancia de las exequias reales para la construcción del poder de la dinastía al decir que "Autre rituel chargé de sens, notamment pour la représentation du pouvoir royal: les funérailles. Comme le rappelle François Chausson, si la mort est le sort commun de tous, celle des souverains se distingue par le fait qu'elle ne passe pas inaperçue. La mort constitue toujours une rupture, mais ses conséquences sont d'une autre nature quand se pose la question de la continuité du pouvoir. Les funérailles royales sont généralement organisées de manière à mettre publiquement en scène cette continuité, tout en glorifiant la puissance du souverain défunt" (Santinelli-Foltz, 2012: 19).
} 
(te deum por batallas ganadas en la guerra de la independencia o por la efeméride revolucionaria).Debemos destacar que a los sermones durante mucho tiempo sólo se los pensó como parte de los oficios religiosos o de la literatura eclesiástica y no habían tenido hasta los últimos años en nuestro medio un tratamiento específico como fuentes históricas. Los nuevos estudios y líneas de investigación los han recuperado como elementos indispensables para entender la formación de mentalidades y su influencia en el contexto histórico de una época (Mariluz Urquijo, 2006, 2010; Martínez de Sánchez, 2008, 2010, 2013, 2014; Di Steffano, 2004, 2010; Ayrolo, 2009; Peire, 2000).

Las fuentes documentales para el análisis serán diecisiete piezas sermonarias pronunciadas durante celebraciones religiosas (advocaciones marianas, te deum y funerales) posteriores al resultado de las batallas o aniversarios de hechos políticos destacados como ya se comentó. Indicamos a continuación, ordenadas cronológicamente, esas fuentes con el detalle del año (cuando ha sido posible determinarlo), autor y la ciudad donde fueron pronunciados (Martínez de Sánchez, 2010: 12). Casi la mayoría de las piezas oratorias a analizar son éditas, alguna contemporáneamente y otras por compiladores posteriores ${ }^{3}$ :

- 1789, Córdoba, Gregorio Funes: Oración Fúnebre por Carlos III (Biblioteca Nacional, 1944: 295-349);

- 1806, Buenos Aires, José Ignacio Grela: Sermón en acción de gracias a la Virgen del Rosario (Grela, 1806);

- 1807, Córdoba, Gregorio Funes: Oración Congratulatoria a Nuestra Señora del Rosario (Castellanos, 1891: 153-169);

- 1807, Charcas, Matías Terrazas: Sermón de acción de gracias por la recuperación de Buenos Aires (Terrazas, 1807);

- 1807, Charcas, Mariano Rodríguez de Olmedo: Oración Fúnebre por los fallecidos en la invasión inglesa (Rodríguez de Olmedo, 1807);

- antes de 1810, Córdoba, fray Pantaleón García: Sermón de Nuestra Señora de Copacabana (García, 1810: 146-162);

- antes de 1810, Córdoba, fray Pantaleón García: Sermón de Nuestra Señora de las Mercedes (García, 1810);

- antes de 1810, Córdoba, fray Pantaleón García: Sermón de Nuestra Señora del Pilar (García, 1810);

- 1812, Tucumán, José Agustín Molina: Acción de gracias por la victoria de Tucumán (Carranza, 1907: 23-41) (Martínez de Sánchez, 2013: 88-99);

- 1812, Santiago del Estero, Juan A. Neirot: Oración Fúnebre por los soldados muertos en Tucumán (Neirot, 1812);

- 1814, Córdoba, fray Pantaleón García: Sermón del 25 de Mayo (Martínez de Sánchez, 2010: 110-122);

3 En aquellos casos que no lo sean se indicará oportunamente (Martínez de Sánchez, 2010, 2013). 


\section{DOSSIER}

Berdini. Santos reyes. Virtuosos incas. Antiguos tiranos: imagen de la monarquía en la homilética sagrada rioplatense...

- 1814, Buenos Aires, Gregorio Funes: Oración patriótica (Martínez de Sánchez, 2010: 123-137);

- 1815, Córdoba, autor desconocido: Sermón del Pilar";

- 1816, Buenos Aires?, franciscano desconocido: Sermón (Martínez de Sánchez, 2010: 138-142);

- 1817, Tucumán, Felipe Antonio de Iriarte: Oración patriótica (Martínez de Sánchez, 2010: 143-158);

- 1817, Catamarca, fray Pedro Luis Pacheco: Sermón de acción de gracias(Martínez de Sánchez, 2010: 159-173);

- 1819, Córdoba, Miguel Calixto del Corro: Sermón panegírico (Martínez de Sánchez, 2010: 174-186);

- posterior a 1821, Buenos Aires (?), autor desconocido: Sermón patriótico (Martínez de Sánchez, 2010: 187-195);

- 1822, Córdoba, fray Pantaleón García: Oración que dijo el Padre... en la Catedral de Córdova el día 25 de Mayo de 1822 (Martínez de Sánchez, 2010: 196-205).

Es de destacar que esta selección de piezas homiléticas cubre un espectro geográfico amplio de ciudades del entonces Virreinato y luego Provincias Unidas, desde Buenos Aires (tres sermones); Córdoba (ocho sermones); Santiago del Estero (un sermón); Catamarca (un sermón), Tucumán (dos sermones) hasta el Alto Perú (dos sermones); en un arco temporal que abarca desde 1789 a 1819. Este lapso de tiempo que toma casi en su totalidad la primera década revolucionaria permitirá acercarnos al discurso eclesiástico sobre el imaginario reyes/monarquía y su cristalización en representaciones retóricas.

\section{Imagen de la monarquía y discurso homilético}

El discurso religioso u homilética sagrada estaba formado por sermones (de acciones de gracia, de santos), oraciones (fúnebres, congratulatorias), pláticas, panegíricos, etc. El vocablo más utilizado para abarcar esta serie de piezas es "sermón" y será el que utilizaremos aquí en función de una mayor practicidad descriptiva y de análisis, aunque existen diferencias de género entre los tipos mencionados (Martínez de Sánchez, 2010: 38-40). Es imprescindible dar una definición del mismo que nos permita anclar esos documentos con la práctica de su oralización y la función que se les otorgaba o se esperaba que tuvieran. Una definición stricto sensu nos plantea que un sermón es un discurso oral enmarcado en una ceremonia litúrgica o reunión religiosa; para los especialistas es sobre todo un texto escrito que ha sido pronunciado por un sacerdote o predicador desde el púlpito y que busca instruir en la fe o exhortar en la moral a una audiencia. Por ello "se emplea por lo general un texto sagrado — no siempre bíblico-

${ }^{4}$ Colección Documental Monseñor Pablo Cabrera (ex Instituto de Estudios Americanistas), Facultad de Filosofía y Humanidades, Universidad Nacional de Córdoba (de aquí en más IEA), documento ํㅜ 11662. 
para explicar o desarrollar tópicos que ayuden a la educación religiosa porque tratan de temas relevantes en muchos casos para el público.” (Flórez, 2010: 74). Ese discurso, en un primer momento oral y para los investigadores escrito, debe ser aquilatado en cuanto a la función que ha tenido como prédica en los contextos sociales donde fue producido y pronunciado y su relación con la evolución histórica de esa sociedad en la cual se producen cambios o mutaciones en lo simbólico, el contenido y estilo de los sermones (Flórez, 2010: 80). Para comprender ese proceso debe prestarse atención a uno de los actores principales del proceso sermón/prédica, el clero. El mismo gozó de preponderante papel de elite intelectual y de "portavoz de los americanos en el proceso de independencia como en ningún otro caso de las revoluciones atlánticas" (Amores Carredano, 2009: 209-210).

El abordaje de esas piezas homiléticas y cómo en ellas se configura la imagen del rey y de la monarquía precisa del utillaje teórico que nos permita entender las representaciones que de ellos poseían los concionadores, las elites letradas a las que pertenecían y la estructura político-institucional que apoyaba o sostenía -o no- esas imágenes y su correlato ideológico. En primer lugar nos acercaremos a las palabras, los epítetos o adjetivaciones que en el marco de las figuras retóricas sustentan, ilustran y persuaden en estos textos. Como afirma François-Xavier Guerra "Normalmente las mutaciones empiezan por el lenguaje. Ante todo la política moderna es una manera nueva de hablar, un nuevo discurso que tiene palabras nuevas y palabras aparentemente antiguas, pero que se remiten a nuevos significados." (Núñez Vega, 2001: 78). Esa "manera nueva de hablar" ya barroca, ya ilustrada o revolucionaria no puede entenderse sin acercarla al momento histórico o encrucijada religioso-política en el cual se desarrollaba, por lo que contextualizaremos esos textos y sus imágenes con la historia en la que se enmarcan. Para ello debemos detenernos primero en el concepto de "rey ausente", esto es, un monarca que gobierna sus tierras americanas desde Madrid y esa figura real no se halla presente sino en autoridades delegadas y sus cortes o funcionarios u objetos simbólicos (virreyes, audiencias, alféreces reales, pendón real, real sello, etc.). El virrey, alter ego del rey, encarnaba en las Indias a ese monarca lejano (Bridikhina, 2007: 554). Ese rey ausente, representación y encarnación de la monarquía, era nombrado, alabado, respetado, idealizado y sacralizado por medio de palabras, gestos, celebraciones, objetos, arte efímero, etcétera: entre esas palabras, unidas a gestos y cierta teatralización, estaban los sermones. En el aparato publicitario de la monarquía se utilizan "imágenes cristalizadas e imágenes vivientes" del poder monárquico: entre las primeras, representaciones figuradas (estatuas, retratos) y atributos (símbolos e insignias reales); entre las segundas se encuentran las diversas ceremonias entre las que ubicamos a las religiosas y los sermones (Santinelli-Foltz, 2012:13). No estarán ausentes de esas liturgias y serán utilizados elementos, como representaciones e insignias, que de manera concreta o retórica se manifestarán favorablemente o desfavorablemente con el monarca. Por último, refiriéndonos ya al período independiente, es necesario remarcar lo afirmado en otro trabajo sobre el uso de la memoria sobre los acontecimientos político-militares y a través de ellos, la construcción de un relato, de una Historia para la Nación, para la Patria. La oratoria sagrada ofrece la posibilidad de acercarnos a esa 
Berdini. Santos reyes. Virtuosos incas. Antiguos tiranos: imagen de la monarquía en la homilética sagrada rioplatense...

operación simbólica central en la elaboración de un relato de la Nación, con una versión de los acontecimientos históricos y de la construcción política de la Patria que no dejaba de lado la participación de la religión en cada uno de los episodios (Clissa, Maggi, Berdini, 2011: 1). Esto se observa en los aniversarios por la Revolución de Mayo o en los funerales por los caídos en los acontecimientos bélicos, donde se ordena la memoria de los mismos y construye una cronografía sobre los hechos iniciáticos, que se presentan como bisagra o puente del nuevo camino histórico emprendido por los americanos, sus protagonistas y necesidades. Sobre esa cronografía volveremos más adelante.

\section{3. "Santos reyes": la monarquía española}

Desde los tiempos del virreinato, en los que gran parte de la población era analfabeta, la Corona era consciente que el sermón era "el medio de comunicación por excelencia" ya que "la persistente reiteración en la misa dominical o en las grandes festividades aseguraba la recepción de un mensaje que no hacía acepción de personas pues se dirigía tanto al rústico como al letrado" (Mariluz Urquijo, 2006: 192). Si, como ya se dijo, partimos de la premisa que los sermones (además de instrumentos de adoctrinamiento) en ciertos contextos no fueron otra cosa que un aparato de propaganda y comunicación estatal, aceptaremos con los autores que en función de ello se utilizaba todo lo que estaba al alcance de la Corona para hablar de sí misma ${ }^{5}$. Así, los triunfos militares, la exaltación al trono del nuevo rey, los nacimientos, enlaces matrimoniales o exequias reales, eran reflejados en las piezas homiléticas. Esos sermones, como construcciones discursivas, permitían mantener el orden social y político apuntalando la unión entre Trono y Altar (Flórez, 2010: 73-74, 85). Sobre este tema se ha referido también Fabián Herrero (Herrero, 2012: 62).

¿Cómo se comunicaban los hechos de la monarquía, cómo se describía a sus protagonistas, los reyes? Según Cortés Guerrero la religión, la Patria y el rey eran elementos indivisos de la defensa de la monarquía y como tal figuran en los sermones (Cortés Guerrero, 2010: 45). Es posible observar este aserto en un sermón de 1806 de acción de gracias por la expulsión de los ingleses de Buenos Aires: [el pueblo acredita su religiosidad y patriotismo] “...dispuesto á derramar su sangre en obsequio de su Fé, de su Rey, de su Patria, de sus familias, de su honor, y de sus intereses?” (Grela, 1806: 14). Mariano Rodríguez de Olmedo en su oración fúnebre por los caídos en las invasiones inglesas planteará esa misma tríada de elementos unidos en 1807: "Unos Católicos que han sacrificado su vida á los derechos de su Rey, á la libertad de su Patria, y al honor de su Religion, parecen á toda luz hijos de los Santos..." (Rodríguez de Olmedo, 1807: 4). Funes por su parte, equipara la sujeción política del rey a la fidelidad a la religión: "...respetable Pueblo que haceis gloria de ser tan fiel al Rey como á la Religion..." (Castellano, 1891: 154). Debemos destacar que a diferencia de los reyes franceses que afirmaban el origen divino de su autoridad, los monarcas españoles justificaban y

\footnotetext{
5 Existían diversas instancias encaminadas a fortalecer la imagen simbólica del rey, como la construcción de grandes palacios, el coleccionismo artístico, la etiqueta cortesana, las ceremonias públicas, las representaciones iconográficas de la majestad real y los discursos cívicos y religiosos (López, 1994: 2).
} 
legitimaban su posición por medio de virtudes, como la sabiduría o la destreza militar y guerrera del monarca (Cortés Guerrero, 2010: 50). La propaganda homilética entonces, mostraba un modelo, un arquetipo de creyente, que al mismo tiempo era gobernante, un rey paternal con un respeto piadoso a la religión. Eran así, los reyes y reinos un espejo de santidad, y sus ejemplos bíblicos y celestiales los reyes veterotestamentarios, los príncipes canonizados y María la Virgen, summum de la realeza y sus virtudes. Carlos IV, por ejemplo, será comparado con el rey David,

"Me figuro, que puesto en la presencia el Dios de la magestad, y penetrado de los afectos de una humanidad verdaderamente christiana, habrá atribuido este golpe á sus pecados personales, y en la amargura de su corazon le habrá dicho á Dios como en otro tiempo el rey David: Señor, yo que soy el rey y el pastor, yo pequé: mis delitos merecen desde luego este castigo; pero mis vasallos que son las ovejas, ¿qué delito han cometido? Ego sum qui peccavi; isti qui oves sunt, quid fecerunt?" (Terrazas, 1807: 41).

La Virgen María tanto en los sermones de fray Pantaleón García como en otros, es descripta como una gobernante con todos los títulos posibles de la realeza, manifestando así el indubitable acatamiento a su gobierno y protección: Reyna triunfadora (García, 1810: 376, 380); gran reyna; gran reyna del cielo (García,1810: 152); soberana reyna (García, 1810: 155) (Grela, 1806: 31); soberana (García, 1810: 151); emperatriz, soberana princesa(García, 1810:147, 152), etc. Nos permitimos aquí un paréntesis para hacer un breve comentario sobre la relación entre monarquía española y la Virgen María. En los sermones el providencialismo está muy presente (Berdini, 2013: 78-81) y los analizados aquí no son la excepción. García en su sermón a "Nuestra Señora del Pilar", expresa que la nación española ha sido elegida por María por una predilección especial (García, 1810: 363, 373) y lo invencible y glorioso del imperio español se debe a ella (García, 1810: 374, 379) que ha protegido "el brazo guerrero de nuestros Soberanos" (García, 1810: 380). Los monarcas medievales, Pelayo, Alfonso I, Alfonso II, Ramiro II o Alfonso XI desfilan en las piezas oratorias, como modelos de héroes militares sostenidos por la providencia divina y el auxilio mariano durante la Reconquista

¿Y de no decirnos quien hizo tan animoso a un Pelayo, para que de aquella cueba memorable en donde se refugio con un exiguo numero de soldados saliesen estos transformados en leones y le hicieron invencibles en todas sus batallas? Quien?Maria en su adbocacion del Pilar, a quien debieron que le volviesen los dardos, y saetas contra los mismos enemigos, que los arrojaban; ¿Quien a aquel glorioso Emperador Don Alfonso el primero al que debio en otro tiempo Zaragoza su libertad, Aragon su restauracion y tranquilidad la Yglecia sus 
Berdini. Santos reyes. Virtuosos incas. Antiguos tiranos: imagen de la monarquía en la homilética sagrada rioplatense...

generosidades, y magnificencias lo hizo tan felis en todas sus acciones. Quien?Maria por cuya intersesion ganó 29 batallas canpales a los moros sirviendo en algunas ella misma de exercito ordenado arrojando rayos contra los enemigos. $i$ Quien a Alfonso $2^{\circ}$ llamado el casto unió tantos trofeos a sus virtudes, que alguna ves contó setenta mil sarracenos como sangriento destroso de su santo zelo? Quien? Maria del Pilar inseparable capitana de sus exercitos en aquella imagen prodigiosa suya que llevaba siempre a la frente de sus tropas ¿Quién a Ramiro el $2^{\circ}$ le dio el que en Simancas con espantoso estrago hubiese abatido el orgullo del soberbio Almansor, y del astuto Albenair? Quien? Maria declarada Adalid valiente en las riberas del Ebro mandando aquellos los Angeles exterminadores /Santiago, y San Millan de la Cogulla para su ruina y confusion ¿Quien exaltó los triunfos de Alfonso 8 en las Nabas de Tolosa? ¿Quien las de Alfonso /el onseno en el Salado? ${ }^{6}$

Dicho de otro modo, la monarquía era lo querido por Dios (Herrero, 2012: 64) y aceptarla era obligado casi como precepto divino. La retórica de los sermones eleva al monarca a un plano cercano al de la divinidad; "Como receptor de una autoridad que venía de lo alto, la persona del rey y sus decisiones eran en la práctica indiscutibles" (López, 1994: 9).

La referencia al rey y en general a la institución monárquica era de exaltación de los mismos, de sus virtudes humanas, políticas y morales (López, 1994: 8, 10), algo que era ordenado por la legislación indiana (Bravo Arriaga, 2001: 27). Ejemplo de ello es la oración fúnebre pronunciada el 28 de abril de 1789 (Llamosas, 2010: 2) por Gregorio Funes en la catedral de Córdoba con motivo de las exequias del rey Carlos III, muerto el 14 de diciembre de 1788 (Martínez de Sánchez, 2011:199-200). Funes lo describirá largamente con títulos, epítetos y descripciones de sus virtudes y accionar. Veremos en su prosa cómo lo define -héroe, piadoso, virtuoso, valeroso, guerrero- y cómo realza sus decisiones en bien del reino. El rey Carlos III es “... un Héroe, á quien Dios previno desde la Cuna con todas las virtudes del Trono para que fuese las delicias de la humildad... ". Ha sido, continúa, "Un REY, que desempeñó con esplendor todas las obligaciones políticas del TRONO: un REY piadoso que cumplió con edificación las obligaciones que impone la Religión..." (Biblioteca Nacional, 1944: 297). Ese rey respetuoso de la religión "conoció a Dios, y siguió paso á paso á la virtud: que fue hijo de la Iglesia y desempeñó plenamente este título." (Biblioteca Nacional, 1944:338-339).

Gregorio Funes define en pocas palabras las que son a su entender, las obligaciones del monarca: "¿Quién no ve descender del Trono estas dos esenciales obligaciones, defender al estado con la fuerza de las armas, y gobernarlo con el imperio de la razón? ... La vida del Héroe, á quien lloramos, es el mejor tratado practico que ha dado á luz el Siglo XVIII sobre estas dos inseparables obligaciones del Reynar."

${ }^{6}$ IEA, documento $\mathrm{N}^{\circ} 11662$, fs. 6 r-6v. 
(Biblioteca Nacional, 1944:297-298). El concionador explicará las virtudes regias que adornaban a Carlos III "Nacido con aquel conjunto de circunstancias que forman el peculiar caracter de los Reyes: Serio sin altivez; respetuoso sin ferocidad; magnifico sin ostentacion, afable sin baxeza; compasivo sin debilidad entró en la carrera de este Mundo, y apenas supo que era hombre, quando ya supo que nacia para REY." (Biblioteca Nacional, 1944:298). Más adelante continúa perfilando al monarca fallecido,

“¿Hubo jamas Monarca mas enemigo del fausto, mas modesto en su vestuario, mas distante de lo frivolo, mas inclinado á lo sólido mas opuesto á la lisonja, mas esento del vano deseo de parecer REY, y por lo mismo mas digno de serlo? ¿Pero qué nos admiramos? La vana gloria es como la sombra, que solo se encuentra al lado los cuerpos retirados del Sol; Carlos estuvo siempre situado en el medio dia de la verdad." (Biblioteca Nacional, 1944: 326)

A todas esas virtudes se le agregan las militares, de central importancia en un monarca, defensor de su reino y súbditos: "Si, Señores, nunca me parece Carlos mas pio, que quando miro su semblante guerrero. Ninguno mejor que él estaba persuadido, que el medio de traer la abundancia pa su Reyno era su propria reputación; que como dice un sabio las lanzas sustentan los olivos; y que Ceres armada del yelmo de Belona hace crecer las mieses." (Biblioteca Nacional, 1944: 306).

Fray Pantaleón García en el sermón de la Virgen del Pilar, caracteriza a los reyes hispánicos por sus contrarios, por los reyes aborígenes, al decir que los primeros pudieron gracias a María que se sirve "ya de una nube de mosquitos para domar el orgullo de los Faraones Motezumas, ya del espanto y terror para abatir el esforzado espíritu de los Incas... dando á la España un nuevo Reyno" (Biblioteca Nacional, 1944: 382). Tildar de "faraones" a los reyes aztecas es darle el título del peor monarca de la historia bíblica, modelo histórico-religioso.

Funes repite aquí la figura discursiva de ubicar en un plano de continuidad y legitimidad al fallecido con los demás reyes: Carlos sabía que “...podia entrar en la cadena de los valerosos Ataulfos, Leovigildos, Recaredos, Pelayos, Ramiros, Alfonsos, Yñigos, Carlos, Fernandos, y principalmente de los Felipes." (Biblioteca Nacional, 1944: 299). Esta ponderación del fallecido está a mitad de camino entre ensalzar la personalidad real y su pertenencia colectiva a una dinastía y a una monarquía (López, 1994: 9).

Otro prelado de nota, como lo fue el obispo fray José Antonio de San Alberto, en su oración fúnebre dada en La Plata (hoy Sucre, Bolivia), comparará al rey borbón con figuras destacadas del Antiguo Testamento, como Moisés y el rey Saúl. El presbítero Mariano Rodríguez de Olmedo por su parte, en 1807, hace un panegírico de Napoleón al ser "socio" (aliado) de "nuestro amabilísimo monarca, nuestro mejor dueño DON CARLOS QUARTO” (Rodríguez de Olmedo, 1807: 10). 
Berdini. Santos reyes. Virtuosos incas. Antiguos tiranos: imagen de la monarquía en la homilética sagrada rioplatense...

La figura paternal del rey, cabeza del reino y representante de la dinastía gobernante es siempre presentada como una figura llena de virtudes tanto políticas, militares como piadosas, siendo ejemplo de mansedumbre, valentía, coraje, piedad y religiosidad.La figura real es además el padre de los súbditos y su falta es motivo de tristezas y angustias. Tal situación es propuesta por el dominico fray José Ignacio Grela en 1806, al describir la invasión de Buenos Aires por los ingleses y la toma del poder: [los habitantes de Buenos Aires] "...abrumados con el doble pesar de no tener ya por padre á un Soberano, á quien aman con entusiasmo..."; "...huérfanos mas de nueve mil personas, que se mantienen a expensas del Soberano..." (Grela, 1806: 16). Su dominio es el mejor frente al del reino britano invasor en 1806: “¿qué mayor desdicha que salir de un dominio suave y paternal para caer en otro tirano y opresivo?" (Castellanos, 1891: 157). El rey es un padre que busca la felicidad del pueblo y la desaparición de sus dolores,

“¡Felices mil veces lo que vivimos en una monarquía cuyos reyes saben ponerse al paralelo de nuestras aflicciones, y mesurar su dicha por la del pueblo! [...] Advertid, hermanos míos, lo que va de un gobierno paternal á un tirano. El carácter bienhechor de nuestro Rey, unido al amor de la justicia, la ha inspirado un reinado dulce y pacífico. A costa de cuantos sacrificios procuró separar de nosotros el cruel azote de la guerra!" (Castellanos, 1891: 167).

En una primera síntesis podemos afirmar que en los sermones estudiados la persona del rey español, encarnación física de la monarquía, es perfilado a través de ciertas características como:

- Rey guerrero/valeroso;

- Rey serio/respetuoso/magnífico/afable/compasivo;

- Rey sabio/justo/paternal/benigno/amabilísimo;

- Rey continuador de la dinastía;

- Rey piadoso/temeroso de Dios/santo

Coinciden estas caracterizaciones con lo planteado por Landavazzo cuando afirma que los sermones manifiestan el paternalismo de un monarca cabeza de la familia española, además de simbolizar la unidad de la monarquía, la cohesión de los territorios y la atemporalidad del presente con el pasado (Landavazzo, 2001: 55-56), siendo una clara demostración de la doctrina del derecho divino de los reyes, que en tanto reyes absolutos, se mostraban como deidades humanas y padres amantes de los vasallos (Rípodas Ardanaz, 2006: 241).Por otro lado, los antimodelos se hallan perfilados en la Biblia, con los faraones egipcios cuyas características presentan los monarcas indígenas aztecas e incas.

\section{Gorro Frigio versus Trono y Corona}

Hasta aquí nos hemos referido a la imagen del monarca y de la monarquía españolas que se perfilan en los sermones de fines del siglo XVIII y principios del siglo 
XIX. A continuación nos aproximaremos al imaginario que sobre ellos se construyó a partir de la Revolución de Mayo.

El proceso político iniciado en la ciudad de Buenos Aires, a partir del 25 de mayo de 1810 significó no sólo un cambio en las estructuras institucionales del poder, sino también en nuevas obligaciones para la Iglesia y los sacerdotes (Berdini, 2014: 37 ). Tanto las jerarquías como los párrocos debían acompañar al movimiento revolucionario con la predicación. Las nuevas autoridades criollas apelaron al clero para que acompañara solidariamente los nuevos procesos socio-político-militares como activo propagandista (Durán, 2010: 3, 6). El clero secular y el regular apoyaron entusiastamente el movimiento; integraron cabildos abiertos, juntas, congresos, ejercieron de capellanes de los ejércitos, etc. Era el grupo más preparado intelectualmente y de prestigio e influencia social, siendo su ascendencia "incomparable sobre el pueblo en general (grandes masas criollas, mestizos e indígenas)” (Durán, 2010: 6).

En los discursos homiléticos estudiados se apela a la memoria y al carácter memorable de ciertos acontecimientos situados tanto en el período precolombino e hispánico como en esa primera década del siglo XIX, en la transición de lo tardocolonial hacia los convulsionados años de la Revolución de Mayo y la declaración de la Independencia. Remarcar lo digno de memoria, lo que debe ser recordado por su importancia, su valor intrínseco, es escribir un relato histórico, una Historia para la Patria. La oratoria sagrada nos permite acercarnos como dijimos a esa operación simbólica central en la elaboración de un relato de los acontecimientos y de la construcción política de la Patria/Nación. En ese relato las efemérides por aniversarios (las fiestas mayas) o el recuerdo de los soldados caídos en batalla, cumplían un papel singular. Los sermones en general aplicarán -entre otras- una figura retórica, la cronografía, para dibujar un nuevo orden de cosas y delinear a unos reyes abyectos y un sistema político

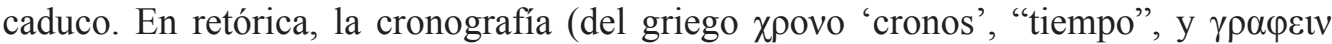
grafía, "describir"), dentro de las figuras literarias, es una de las figuras de definición; consiste en una descripción de tiempos, entendidos éstos por momentos temporales determinados (Vázquez Rodríguez, 2004: 56) (Torradillos, 1867: 38). La cronografía en estas piezas homiléticas señala la existencia de tres momentos bien diferentes: la etapa precolombina, la etapa española y la etapa revolucionaria. El divisorio de aguas entre las dos primeras se dio por el descubrimiento de América; y entre ésta y la siguiente por la Revolución de Mayo. Esos hitos marcan un antes y un después que determinará períodos con fuertes imágenes y representaciones de la etapa aborigen con sus gobernantes y por otro lado, el final del absolutismo y de la monarquía dará paso a una etapa de "regeneración" más cargada de republicanismo.

\section{5. "Virtuosos incas": los reyes aborígenes}

Los sermones pronunciados a partir de 1810, que han sido caracterizados como cívicos o patrios, tenían, entre otros, un objetivo que era convencer al auditorio de las bondades del nuevo sistema político, surgido el 25 de mayo de 1810 y por ende, de lo errado y malo de la monarquía hispánica e iniciar una nueva etapa histórica con la guía 
Berdini. Santos reyes. Virtuosos incas. Antiguos tiranos: imagen de la monarquía en la homilética sagrada rioplatense...

de líderes heroicos y virtuosos. Así se colaboraba con la memoria de un pueblo que avanzaba hacia su independencia, convirtiendo al púlpito en un vehículo propicio para transmitir el origen y el porqué de la libertad (Clissa, Maggi, Berdini, 2011: 2). Para ello se apela a una adjetivación recargada, una caracterización entusiasta, propia del fervor patriótico y de su similitud a arengas políticas, destinadas a exhortar y convencer (Ayrolo, 2009). Esa adjetivación marca un hiato entre el pasado (representado por España, sus reyes, su gobierno, su sistema político) y el presente, el nuevo sistema, que al estilo de los gobiernos precolombinos, es muy distinto al español. Observamos en los sermones que, de acuerdo a las palabras y frases empleadas, es posible señalar tres momentos reseñados por los sacerdotes, el precolombino, el español y el revolucionario. Esa cronografía nos describe la historia americana con similitudes a la bíblica: el paraíso (lo aborigen), la caída (lo español) y la redención (lo revolucionario). Aquí nos detendremos en el análisis de la imagen de la monarquía y de los reyes, pero de reyes no españoles. En la citada cronografía, las Indias españolas antes de la conquista tuvieron gobiernos con testas coronadas cuyas descripciones nos acercan al ideal pregonado con anterioridad (tanto en virtudes, acciones, características, etc.).Los concionadores no ahorran el uso de epítetos positivos e hipérboles para caracterizar a América, sus monarcas autóctonos y sus súbditos, que resaltan por sus figuras similares a las de los más famosos gobernantes de la Antigüedad Clásica grecorromana,

"Es necesario confesar que los Americanos nacieron independientes, Soberanos, ádvitros, y jueces de sus acciones; y usando de esta libertad propria del hombre, se governaron muchos Siglos, ya bajo el Imperio paternal; ya bajo una Cabeza, que llebaba la Voz, ya bajo la Sombra de los Soberanos de México, y Perú: personages morales, que uniendo en sus manos, y en su Espíritu la fuerza; y la razón de la parte más pingue de la América, la pusieron en estado de Seguridad: la ilustraron con leyes gravadas al par de las que dictaron Minos en Creta, y Licurgo en Esparta: la civilizaron con política tan fina, que si no excede, se Anibela, con la de Roma, y Grecia. Los Tronos de Motezuma, y Athahualpa, esparcieron en casi todo el continente los resplandores del oro de que se formaban, y acreditaron que se sentaban en ellos Monarcas dignos de serlo." (Martínez de Sánchez, 2010: 112)

Gregorio Funes en 1814 describirá a los aborígenes como gente "sin mal", en un estado casi de inocencia edénica, "... lo menos, los Indios tenían pocas necesidades, y vivían sin inquietud en una dulce indolencia: humanos sin malicia, sin espíritu de venganza, y casi sin pasiones eran felices: su historia y su moral se hallaban encerrados en una colección de canciones, que se les enseñaba desde la infancia: los Peruanos tenían sus Quipos, y los Mexicanos sus pinturas.” (Martínez de Sánchez, 2010: 127). En la misma línea, un sacerdote desconocido, criticando a los reyes españoles y a sus representantes en América, los virreyes, dirá de los indios peruanos que fueron vencidos 
y que su principal valor era la virtud, "Los Virreyes fastuosos, que como dice un sabio Filósofo enervados por la codicia y los placeres, han dormido insolentemente sobre las cenizas de los virtuosos Incas..." (Martínez de Sánchez, 2010: 190).

Unos años antes, el sacerdote secular de Santiago del Estero, Juan Antonio Neirot, potenciará esa visión de la sociedad aborigen al decir que era la "república de Platón, la utopía de Tomás Moro",

No faltó más de este suelo americano, para que fuese un noviciado del reino de los cielos, que la religión católica. $\mathrm{Su}$ gobierno dijo el conde Carli, que solo era posible, porque había existido: la república de Platón, la utopía del venerable Tomás Moro, parece tuvieron su existencia en este continente: habitantes desconocidos en el antiguo mundo se reunieron en el nuevo á formar una numerosísima familia: estrechados íntimamente en los vínculos de la sociedad, no había entre ellos más que una perfecta consonancia de las partes con el todo, un solo corazón y una sola voluntad. (Neirot, 1812: 15)

Miguel Calixto del Corro en un sermón por el aniversario del 25 de mayo describe las tierras americanas asimismo como un remedo del Jardín del Edén,

Que la América haya debido ser un país libre e independiente, nos lo manifiestan los muchos y dilatados siglos en que lo fue, su misma situación local, los inmensos mares que la circundan, y las proporciones y ventajas de que disfruta. Dotada por la naturaleza de cuanto encierra y produce el mundo antiguo, ella no necesitó jamás de sus producciones, y menos de su administración para ser feliz. Su riqueza es una producción espontánea tan abundante, que ella sola forma el círculo y comercio del mundo entero, y las producciones de su inmenso y fecundo suelo tan varias y feraces, que casi no necesitan de la industria. En una palabra: en ella nada se echa de menos de cuanto pudiera hacer un imperio opulento y feliz. Así es que el de Méjico y Perú habían llegado a un grado de prosperidad y perfección, que no gozó ningún otro en su adolescencia, y que aún no dejan de admirar las naciones cultas. La naturaleza pues hizo a la América un país libre e independiente. (Martínez de Sánchez, 2010: 176)

Así como los habitantes del suelo americano eran hombres sin malicia, sus gobernantes eran dechados de virtudes. Fray Pantaleón García pondrá a un mismo nivel o en todo caso en uno superior a los reyes aborígenes al compararlos con los del Viejo Mundo, al decir que "Motesuma, Atabaliba, esos príncipes dignos de un trono, que obscurecía con los brillos de su política y riquezas los de Europa..." (Martínez de Sánchez, 2010: 196). 
Berdini. Santos reyes. Virtuosos incas. Antiguos tiranos: imagen de la monarquía en la homilética sagrada rioplatense...

Debemos destacar que durante un tiempo en que se debatió en el congreso constituyente de Tucumán sobre la forma de gobierno a instalar, hubo una fuerte línea de opinión que bregaba por la organización política de las Provincias Unidas como una monarquía temperada (parlamentaria) con un heredero o descendiente de los emperadores incas que asumiría el gobierno con el título de rey (Lozier Almazán, 2011). Esta corriente incaísta rioplatense, al decir de Rípodas, hace que "Cada aniversario de Mayo [...] se presta a un ejercicio retórico tendiente a evocar un envidiable pasado incaico destruido por un puñado de conquistadores sanguinarios." (Rípodas Ardanaz, 1993: 228-230).

Este discurso filoaborigen no tenía correlato en otras regiones de América del Sur, ya que en el Perú entre 1780 y 1805 el "discurso nacionalista inca fue sustituido por el discurso nacionalista criollo", habiéndose desterrado definitivamente tal idea entre 1805 y 1825, "por la sombra del miedo a la gran revolución tupamarista." (Gonzáles, 2012: 18).

En síntesis, los reyes aborígenes, tanto incas como aztecas, se nos presentan como:

- Reyes morales/dignos/soberanos/independientes/paternales;

- Reyes brillantes/ricos;

- Reyes del paraíso/de la República de Platón/de la utopía de Tomás Moro

Pero esa imagen de la América paradisíaca con gobernantes modélicos, construida por los predicadores, se verá invadida por los europeos. Los reyes de España y sus enviados/conquistadores trastocarán todo lo bueno y provocarán su degeneración, según los concionadores revolucionarios.

\section{6. "Antiguos tiranos": reyes españoles}

Si el objetivo a partir de la Revolución era sostener el nuevo proyecto político y socavar la imagen sacralizada del rey y de la monarquía que se había inculcado en las representaciones mentales colectivas, debía apelarse a recursos psicológicos que activaran resortes emocionales y sentimientos (Carman, 2007: 28-29). Esos recursos debían demostrar que los reyes "santos" ya no lo eran y que, por el contrario, todo lo que hicieron, particularmente en América, fue negativo y repudiable. A partir de aquí, los predicadores pondrán todo su poder argumentativo para justificar el porqué de llamar a la conquista y colonización "la obra más odiosa a los ojos del Criador", con un largo sinfín de hechos negativamente descriptos, personajes de pésimo accionar y unas consecuencias cuasi-apocalípticas para los habitantes americanos contemporáneos a la conquista y contemporáneos al sermón. Nos permitimos citar in extenso un párrafo que ejemplifica lo dicho,

Ni pretendo traer a la memoria la conducta que observaron los Españoles todo el tiempo que nos dominaron. Esto sería querer encerrar en una copa las aguas del océano. Nadie ignora que ellos entraron en este imperio dominados de una vil codicia 
para saciar su ambición, y otras pasiones vergonsosas que en sentir del Padre Casas fueron las más crueles leyes vigentes que pueden imaginarse. Preguntadles qual ha sido el fin de Atahualpa, [...] y de los otros Príncipes, y Señores de este Imperio? Qué se ha hecho esa colmena de habitantes en la expresión del Padre de los Americanos, que a la vuelta de 3 Siglos con la introducción de tanta nación extranjera aún es un desierto? [...] que unos fueron entregados a las llamas, aquellos a la espada, y otros a las bestias. Ah! Mientras hayan piedras y bosques en América no oirán sin espanto los nombres de los Colones, de los Pisarros, de los Mendosas, de los Garajes, de los Salvadores, de los Almagres y de los otros opresores de la humanidad que estuvieron en esta memorable conquista (Martínez de Sánchez, 2010:140)

Nuevamente se apela a la cronografía para denostar esa etapa, la del descubrimiento y conquista. En ese contexto de independencia, de moralidad de los soberanos aborígenes, al mismo tiempo creadores de una fina legislación, se produce el descubrimiento por Cristóbal Colón, puerta a futuras desdichas, "Descubriendo el gran Colón este nuevo Mundo, y haciéndose instrumento de Reyes ambiciosos, abrió el camino a insaciables Conquistadores, que devoraron las tierras, y los hombres; levantó el anfiteatro al triunfo más lúgubre de las pasiones, y vino a ser el descubrimiento de la América la obra más odiosa a los ojos del Criador" (Martínez de Sánchez, 2010: 125). Gregorio Funes agregará un poco más adelante, "Qué derechos tubieron los Reyes de España para atar al carro de su fortuna a los Motezumas, y a los Incas, y apoderarse de sus Imperios?” (Martínez de Sánchez, 2010: 125). Las tierras americanas, que son consideradas el remedo del paraíso en la tierra, serán sometidas junto con sus habitantes a la presencia y maldades de los españoles, quienes transformarán ese edén en el inicio de una etapa negativa en todos los sentidos,

Pero en medio del goce de estas felicidades aparecen los peninsulares de Europa. ¡Ah desgraciados días! Desde este momento comenzó el paraiso americano á transformarse en el más lamentable teatro de sangre, de ruina y desolación. Introdujeron su dominación no solo tiránica en el título si también en el ejercicio. [...] Plegué á Dios y hago testigos á todos los coros de los ángeles, y á toda la corte celestial, que por quince millones de indios que los españoles han muerto, sin darles la agua del bautismo infernando sus almas, y por lo que leo en las sagradas escrituras, algún día será la España enteramente arruinada y desolada». (Carranza, 1907: 15-16) 
Berdini. Santos reyes. Virtuosos incas. Antiguos tiranos: imagen de la monarquía en la homilética sagrada rioplatense...

Como corolario a ese accionar de negatividad superlativa Funes exclamará que

El hombre perverso rompe los nudos que lo unen a la sociedad civil: el político injusto, el Soberano ambicioso rompe aquellos, que lo estrechan a la sociedad universal. Ved aquí el crimen de los Reyes de España contra las potestades de la América. La confianza que les inspiraron sus fuerzas, y la esperanza de la impunidad fueron las causas de esos excesos, que deben mirarse como el monumento más bien caracterizado del despotismo y la tiranía.” (Martínez de Sánchez, 2010: 126)

El deán cordobés demolerá con sus palabras asertos planteados por él mismo décadas antes, cuando diga que los reyes españoles lejos estuvieron de cumplir con los preceptos bíblicos, "Con todo: los Reyes de España toman las palabras de Jesu-Christo en el sentido que más favorece su política, y después de largas combinaciones, que les hace formar el interés. Con el Evangelio en una mano, y la Espada en la otra se abren un camino de sangre a las Américas.” (Martínez de Sánchez, 2010: 127). De inmediato pasa a describir mediante contrarios lo que debieron ser y no fueron, en una lista de sustantivos que se oponen y adjetivos que disminuyen lo positivo y bueno,

El Príncipe siempre débil, o engañado, expuesto a la infidelidad $\mathrm{y}$ al terror, se encontraba constantemente entre la impotencia de conocer, y la necesidad de obrar. Por otra parte; criados en una Corte donde se juntaban todos los vicios desde las extremidades de la Monarquía, podría ser el alma de estos Reyes austera y pura? Habrían aprendido a despreciar las riquezas, donde la riqueza era la medida del honor? ¿A huir del fausto, [sic] donde el luxo corrompía hasta los pobres? A ser humanos, donde el poderoso oprimía al débil? A tener costumbres, donde el vicio había perdido toda su infamia? (Martínez de Sánchez, 2010: 128).

A ese catálogo de características nefastas de los políticos/príncipes se incorpora la presencia tangible de los mismos en suelo americano a través de sus principales funcionarios delegados, los virreyes: "Los Virreyes fastuosos, que como dice un sabio Filósofo enervados por la codicia y los placeres, han dormido insolentemente sobre las cenizas de los virtuosos Incas..." (Martínez de Sánchez, 2010: 190).Un sacerdote cuyo nombre no ha llegado a nosotros dirá en su sermón que en épocas pasadas se buscaba (por diversos medios, incluidos los sermones) que los habitantes de América debían persuadirse de la diferencia entre los monarcas y los súbditos, diferencia rayana en lo celestial, "Todo se puso en práctica a fin de persuadirnos que sus monarcas casi eran otra especie que la nuestra, y que sus caprichos llevaban siempre el carácter sublime de la ley. [...] ¿Será extraño que extraviada así la opinión pública, se nos pidiese por los príncipes un culto casi igual que la divinidad?” (Martínez de Sánchez, 2010: 190). 
Específicamente, algunas piezas homiléticas se referirán a reyes en particular y los harán protagonistas del momento histórico y censurarán su accionar mostrándolos más como enemigos que como "señores paternales". Así, fray Pantaleón García dice que "Los Borbones abandonan la España; ¿Y no es de razón no seguir las banderas de unos Reyes, que entregaron su Pueblo al Enemigo, como rebaño de esclavos?" (Martínez de Sánchez, 2010: 116). Aquí el fraile hace referencia al momento en que tanto Carlos IV como su hijo Fernando VII estuvieron encarcelados en Francia, luego de la farsa de Bayona. Se explaya aún más justificando el final del gobierno español en la responsabilidad del último Borbón gobernante, "Si Fernando nos abandonó, si perdió el derecho a exijir nuestra obediencia; si sus representantes a quienes jamás hemos jurado, han embilecido nuestros derechos se rompió el contrato, se acabó el juramento." (Martínez de Sánchez, 2010: 118) Casi en la misma línea de argumentación, Neirot dirá que América está "A la sombra de un rey que no existe" (Neirot, 1812: 18).

Miguel Calixto del Corro en 1819 describe la situación de España y de sus líderes de la siguiente manera: "Tal fue la inicua y perversa administración de Godoy, la indolencia y abandono del Rey Carlos, los celos e imprudencia de Fernando, y sobre todo los manejos secretos y ambiciosos del tirano de la Europa." (Martínez de Sánchez, 2010: 178-179). Se detiene luego en Fernando VII quien "se deja ver al contrario con toda la majestad de un déspota, y el aparato de un tirano, anulando de un golpe las Cortes generales de la Nación, prohibiendo con las mayores penas su nueva Constitución, y lo que es peor, en vez de entrar repartiendo bendiciones y premios, fulmina anatemas y proscripciones, cárceles y destierros, muerte y suplicios contra sus mejores defensores." (Martínez de Sánchez, 2010: 183).

En la cronografía mencionada con anterioridad, más los juicios de valor sobre los acontecimientos políticos de España, se observa una construcción de la figura de los reyes en general, de Carlos III, Carlos IV o Fernando VII en particular y de la monarquía como sistema de gobierno. Esa construcción se funda sobre los pilares de una leyenda negra y discursos panegíricos sobre la etapa independiente. La homilética sagrada fue así un instrumento, con fuerte contenido doctrinal e ideológico, de crítica al régimen en decadencia y de defensa del nuevo orden político. Su finalidad, además de construir modelos ideales de comportamiento (valores, ideas y representaciones desde la cosmovisión católica) fue la de crear y difundir opinión, sobre la legitimidad del gobierno revolucionario y denostar a la Corona española. Por ello los reyes españoles desfilan en los discursos sacros como,

- Reyes españoles en general: ambiciosos, tiranos, insaciables, conquistadores, profanadores, criminales, caprichosos;

En particular, cuando los sermones se refieren a algún rey con su nombre, son explícitos al describirlos,

- Rey Carlos IV: indolente; abandónico;

- Rey Fernando VII: abandónico; inexistente; celoso; imprudente; déspota; tirano; anatematizador; etc. 
Berdini. Santos reyes. Virtuosos incas. Antiguos tiranos: imagen de la monarquía en la homilética sagrada rioplatense...

\section{Palabras Finales}

El sermón fue un elemento central de las ceremonias religiosas, realizadas al interior de las conmemoraciones cívicas de hechos políticos, que fueron espacios de construcción de la historia y de la aceptación de ideas, costumbres y mentalidades. Los predicadores, como miembros de la Iglesia que apoyaron la Revolución de Mayo, conformaron, construyeron y difundieron un discurso sobre hechos memorables/dignos de memoria; como la guerra de la independencia, sus batallas y héroes militares. Los sermones, las oraciones patrióticas en oficios de acción de gracias y las oraciones fúnebres fueron utilizados para construir la memoria de los acontecimientos que cimentaban la historia reciente y justificaban el accionar político y económico de los gobiernos, sacralizados desde la cátedra eclesiástica (Martínez de Sánchez, 2014: 34). Esos sermones funcionaban como discursos que proporcionaban información de hechos destacados, difundiendo a un auditorio amplio las últimas noticias, principalmente bélicas. Esos hechos pasarían a formar parte de la memoria del pueblo, respaldada por la Iglesia, que los colocaba a un mismo nivel que las festividades religiosas. No sólo para la sacralización de la figura real, de la dinastía y el sistema monárquico será utilizado el sermón sino también se constituirá en elemento o instrumento para denostar todo ello de la manera más dura y explícita. Así, se construirá una narración histórica o relato de los orígenes de la Nación, con una versión de los acontecimientos históricos y de la construcción política de la Patria que no dejaba de lado la participación de la religión en cada uno de los episodios. Esa memoria se cristalizaba en una cronografía, en un tiempo definido y descripto con caracteres que se repetían y amplificaban en múltiples adjetivaciones y definiciones negativas o positivas. Así una etapa histórica similar al paraíso en la tierra (la precolombina) era sucedida por otra de oscuridad y desdichas (la hispánica) y ésta por otra de regeneración (la independiente). Constantemente se apela a una terminología de oposiciones, donde la dualidad (bueno/malo) muestra una realidad bifronte (tiranía/libertad, monarquía/nuevo sistema) (Consigli, 2008: 165).En ese marco general hallamos una representación del sistema político monárquico, de la figura del rey y de sus características. El discurso concionador de la etapa hispánica resaltaba la figura del monarca, rey absoluto que era al mismo tiempo deidad humana y padre amante de sus vasallos (Rípodas Ardanaz, 2006: 241), una especie de "rey santo" que velaba por el bienestar de sus súbditos con el beneplácito de Dios, de quien emanaba su poder absoluto, su derecho a gobernar. El movimiento emancipatorio provocará una bisagra en la política, la homilética y en definitiva la mentalidad sobre las testas coronadas. En primer lugar, se recuperarán las figuras de los príncipes indígenas de México y Perú, trasladando los epítetos de aquellos gobernantes españoles a éstos: no habrá mejor ejemplo de personas reales, por derechos, por moralidad, que los emperadores aztecas e incas. Por el contrario, frente a estos "reyes virtuosos" autóctonos, los gobernantes ibéricos se transforman en criminales, por ellos mismos, por sus delegados en América tanto conquistadores como virreyes. En general, comparten asertos negativos que se repiten y amplían en adjetivaciones que sólo muestran a "reyes tiranos" para con los indios en particular y los americanos en general. Algo que, según su óptica, se acentuó en la primera década del siglo XIX con Carlos IV y Fernando VII que lejos estaban de 
encabezar como reyes cuasi canonizados un territorio americano que intentaba desmontar esa imagen repetida pocas décadas antes y que culpaba a ellos y sus antecesores de los males de América.

\section{Fuentes}

Colección documental "Mons. Dr. Pablo Cabrera", Biblioteca Central de la Facultad de Filosofía y Humanidades "Elma Kohlmeyer de Estrabou”, Universidad Nacional de Córdoba. Ex Instituto de Estudios Americanistas.

Doc. 11662 "Sermón del Pilar"

\section{Referencias Bibliográficas}

Amores Carredano, J.B. 2009. "En defensa del rey, de la patria y de la verdadera religión: el clero en el proceso de independencia de Hispanoamérica", 209-234. En: Amores Carredano, J. B. (coord.) Las independencias iberoamericanas: ¿un proceso imaginado?, Bilbao, Servicio Editorial Universidad del País Vasco.

Ayrolo, V. «El sermón como instrumento de intermediación cultural. Sermones del federalismo cordobés, 1815-1852», Nuevo Mundo Mundos Nuevos [En ligne], Débats, mis en ligne le 13 novembre 2009, consulté le 28 juillet 2015. URL: http:// nuevomundo.revues.org/57521; DOI: 10.4000/nuevomundo.57521, consultado 20 de marzo de 2016.

Berdini, J. A. 2013. "Sermones, batallas y victorias: providencialismo y patrocinio guerrero de la Virgen María en la homilética sagrada (1806-1812)”. En: Martínez de Sánchez, Ana María (dir.). Cátedra, púlpito y confesionario. Hacer y decir los sermones, Centro de Investigaciones sobre Cultura y Sociedad (CIECS), Córdoba, Báez Ediciones, pp. 75-99.

Berdini, J.A. 2014. “América, espejo de Grecia y Roma: tradición clásica en el púlpito rioplatense (siglos XVIII-XIX)”. En: Martínez de Sánchez, Ana María (dir.). Algunos sujetos y objetos de la oratoria sagrada en América Colonial, Programa de Estudios Indianos, Córdoba, CIECS-UNC, pp. 33-52.

Biblioteca Nacional, 1944. Archivo del Doctor Gregorio Funes. Deán de la Santa Iglesia Catedral de Córdoba, Buenos Aires, Imprenta de la Biblioteca Nacional, Tomo I.

Bravo Arriaga, M.D 2001. "Un sermón de profesión de monjas del siglo XVII: la retórica de la perfección”. En: Caravelle, N 76-77, pp. 391-399.

Bridikhina, E. 2007. "La ciudad y la corte como espacios de poder en Hispanoamérica. La Plata colonial”, Revista de Indias, vol. LXVII, N²40, pp. 553-572.

Carman, C. 2007. "El clero independentista del Río de la Plata ante el proceso revolucionario. Los casos de Pedro Ignacio de Castro Barros y de Julián Segundo de Agüero"...Bibliographica Americana, Abr. 2007, n. 4.

Carranza, A. P. 1907. El Clero Argentino de 1810 a 1830, Museo Histórico Nacional, Buenos Aires, Imp. de M. Rosas, Tomo I. 
Berdini. Santos reyes. Virtuosos incas. Antiguos tiranos: imagen de la monarquía en la homilética sagrada rioplatense...

Castellanos, U. 1891. Ave María. La milagrosa imagen de Nuestra Señora del Rosario que se venera en el Convento de Predicadores en la ciudad de Córdoba (República Argentina). Apuntes históricos sobre su Origen, Culto y Favores muy señalados que han obtenido sus devotos, Córdoba, La Minerva.

Clissa, K, T.R. Maggi y J A. Berdini, "Púlpito y Memoria. La construcción de la Patria a partir de sermones postcoloniales". En: Encuentro Internacional Fecundidad de la memoria. Desafíos del presente a los usos del pasado en América Latina, Centro de Estudios Avanzados, Programa de Estudios sobre la Memoria, Universidad Nacional de Córdoba, 14, 15 y 16 de noviembre de 2011, Córdoba, Argentina. En: http://www.cea.unc.edu.ar/memoria/trabajos.php

Consigli, J. 2008. “Citas latinas en sermones coloniales de confesión y de ánimas”. En: Martínez de Sánchez, A.M (comp.) Oralidad y escritura. Prácticas de la palabra: los sermones, Córdoba, Programa de Estudios Indianos, CEA-UNC.

Cortés Guerrero J.D. 2010. "La lealtad al monarca español en el discurso político religioso en el Nuevo Reino de Granada". En: Anuario Colombiano de Historia Social y de la Cultura, Bogotá-Colombia, vol. 37, n 1, pp. 43-83.

Di Stefano, R. 2010. Ovejas negras. Historia de los anticlericales argentinos, Buenos Aires, Sudamericana.

Di Stefano, R. 2004. El púlpito y la plaza. Clero, sociedad y política de la Monarquía Católica a la República Rosista, Buenos Aires, Siglo veintiuno editores.

Durán, J.G 2010“La Iglesia y el movimiento independentista rioplatense. Incertidumbre, aceptación y acompañamiento (1810-1816)”, Curso de Extensión “El Bicentenario y nosotros mañana", Facultad de Teología, Pontificia Universidad Católica Argentina Santa María de los Buenos Aires, www.uca.edu.ar/teologia.

Fenoglio, N.C. 2010. Catálogo de sermones de la Colección Documental "Mons. Dr. Pablo Cabrera", Córdoba, Programa de Estudios Indianos, Centro de Estudios Avanzados, UNC.

Flórez, G.C 2010. "El sermón en el Perú de los Austrias y su relación con la génesis del Estado moderno", Investigaciones Sociales, Lima, Perú, UNMSM/IIHS, Vol.14, $\mathrm{N}^{\circ} 25$, pp. 71-87.

García, P. 1810. Varios Sermones Panegíricos, Madrid, Imprenta de Collado.

Gonzáles, D. A. 2012. "La imagen de los incas e indígenas en la opinión de los criollos y españoles (1780-1800)". En: Illes Imperis, 14, pp. 167-188.

Grela, J. I. 1806. Sermón predicado en la Iglesia de Predicadores de Buenos-Ayres, en la solemnísima accion de gracias que con asistencia de la Real Audiencia, Señor Obispo, Ilustre Cabildo, Prelados Regulares, y Real Colegio de San Carlos, consagro a MariaSantisima del Rosario, el Señor Capitan de Navio Don Santiago Liniers, y Bremont por haber reconquistado baxo su patrocinio dicha Ciudad, el doce de Agosto de mil ochocientos seis.

Herrero, F. 2012. "La idea de la independencia durante los días de la Revolución americana y de la Restauración europea. El difícil sermón patriótico de Francisco Castañeda en la Catedral de Buenos Aires”, Iberoamericana, XII, 45, 59-79. 
Landavazzo, M. A. 2001. "El imaginario monárquico en la Nueva España de 1808: coyuntura política y mentalidad histórica”, Tzintzun. Revista de Estudios Históricos, $\mathrm{N}^{\circ}$ 34, julio-diciembre, pp. 35-72.

Llamosas, E. 2010. “Vos das los imperios, vos los quitas: el Deán Funes y su oración fúnebre a Carlos III (1789)”. En: Revista de Historia del Derecho, Buenos Aires, Instituto de Investigaciones de Historia del Derecho, $\mathrm{N}^{\circ} 39$, ene./jun.

López, R. J. 1994. "La imagen del rey y de la monarquía en las relaciones y sermones de las ceremonias públicas gallegas del Antiguo Régimen”. En: Semata. Ciencias Sociais e Humanidades, 6, pp. 197-222.

Lozier Almazán, B. P. 2011. Proyectos monárquicos en el Río de la Plata: los reyes que no fueron, Buenos Aires, Sammartino Ediciones.

Mariluz Urquijo, J. M. 2006. "La predicación rioplatense frente al poder durante el siglo XVIII", Revista de Historia del Derecho, Buenos Aires, Instituto de Investigaciones de Historia del Derecho, $\mathrm{N}^{\circ} 34$, pp. 191-212.

Mariluz Urquijo, J. M. 2010. "La sociedad rioplatense del siglo XVIII a través de los sermones", Biblioteca Virtual Cervantes, pp. 1-16.

Martínez de Sánchez, A. M. (comp.). 2008. Oralidad y escritura. Prácticas de la palabra: los sermones, Córdoba, Programa de Estudios Indianos, CEA-UNC.

Martínez de Sánchez, A. M. (dir.). 2013. Cátedra, púlpito y confesionario. Hacer y decir los sermones, Córdoba, Programa de Estudios Indianos, CIECS, Báez Ediciones.

Martínez de Sánchez, A. M. (dir.). 2014. Algunos sujetos y objetos de la oratoria sagrada en América Colonial, Córdoba, Programa de Estudios Indianos, CIECS-UNC.

Martínez de Sánchez, A. M. 2010. El valor de la palabra en sermones patrios ¿Libertad o independencia?, Córdoba, Programa de Estudios Indianos, CEA-UNC.

Martínez de Sánchez, A. M. 2011. Formas de vida cotidiana en Córdoba (1573- 1810) Espacio, tiempo y sociedad, Córdoba, Centro de Investigaciones y Estudios sobre Cultura y Sociedad.

Neirot, J. A. 1812. ORACIÓN FÚNEBRE Que en las solemnes exequias de los valientes soldados que murieron en la defensa de la patria en la ciudad de Tucumán el día 24 de septiembre de 1812 celebradas el día 7 de octubre en esta Santa Iglesia Matriz de Santiago del Estero dijo el Maestro D. Juan Antonio Neirot, Juez hacedor de diezmos de dicha ciudad, Buenos-Ayres, Imprenta de Niños Expositos.

Núñez Vega, J. 2001. "Palabras, prácticas, imaginarios. Entrevista con el doctor Francois-Xavier Guerra”, Illes i Imperis, 4, primavera, pp. 77-82.

Peire, J. 2000. El taller de los espejos. Iglesia e Imaginario 1767-1815, Buenos Aires, Ed. Claridad.

Rípodas Ardanaz, D. 1993. "Pensamiento incaico y pensamiento político rioplatense", Jahrbuch für Geschichte Lateinamerikas, No 30, pp. 227-258.

Rípodas Ardanaz, D. 2006. "Versión de la monarquía de derecho divino en las celebraciones Reales de la América borbónica", Revista de Historia del Derecho, $\mathrm{N}^{\mathrm{o}}$ 34, Buenos Aires, Instituto de Investigaciones de Historia del Derecho, pp. 241-267. 
Berdini. Santos reyes. Virtuosos incas. Antiguos tiranos: imagen de la monarquía en la homilética sagrada rioplatense...

Rodríguez de Olmedo, M. 1807. Oracion Funebre en las solemnes honras, que en sufragio de los individuos que fallecieron en la Capital de Buenos-Ayres, peleando contra los Ingleses desde el dia dos al seis de Julio del presente año de 1807, se celebraron en la Santa Iglesia Metropolitana de la ciudad de la Plata el dia siete de Agosto del mismo año: con asistencia del Exmo. Sr. Presidente, Real Audiencia, Cabildo Eclesiástico y Secular, y habiendo celebrado de Pontifical su dignísimo Arzobispo el Illmo. Sr. Dr. D. Benito Maria de Moxó y de Francoli: predicada por el Dr. D. Mariano Rodriguez de Olmedo, Prebendado de la misma Santa Iglesia, Colegial y Rector Antigüedad, que fue del insigne de Málaga, de la Real Universidad de Alcalá de Henares, \&, Buenos-Ayres, Real Imprenta de los Niños Expósitos.

Santinelli-Foltz, E, Schwentzel C.-G. (dir).2012. La puissanceroyale. Image et pouvoir de l'AntiquitéauMoyenÂge, Rennes, PressesUniversitaires, Rennes.

Terrazas, M. 1807. Sermon de accion de gracias, con motivo de la restauracion de Buenos-Ayres, pronunciado en la Santa Iglesia Metropolitana de Charcas, por el D. D. Matias Terrazas dignidad de Tesorero de dicha Sta. Iglesia. Reimpreso en Lima.

Torradillos, Á. M. 1867. Lecciones elementales de Retórica y Poética por el Doctor y Catedrático Don..., Imprenta y Librería de los Hijos de Vásquez, Madrid.

Vázquez Rodríguez, F. 2004. La cultura como texto. Lectura, semiótica y educación, Pontificia Universidad Javeriana, Bogotá. 